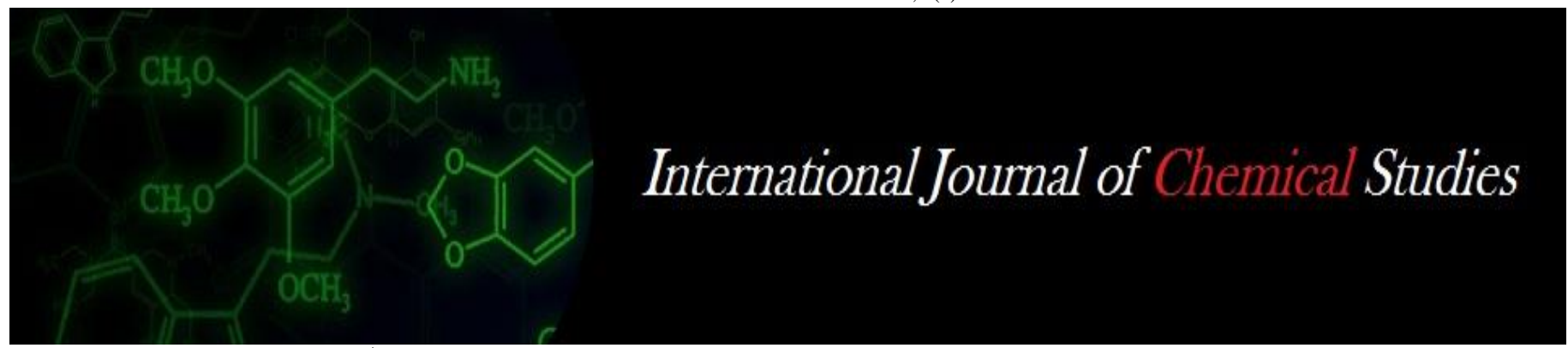

P-ISSN: 2349-8528

E-ISSN: 2321-4902

www.chemijournal.com

IJCS 2020; 8(1): 2953-2955

(C) 2020 IJCS

Received: 11-11-2019

Accepted: 15-12-2019

\section{AG Ghaghara}

Department of Plant Pathology, Junagadh Agricultural

University, Junagadh, Gujarat,

India

\section{VV Rajani}

Department of Plant Pathology,

Junagadh Agricultural

University, Junagadh, Gujarat,

India

\section{Bhaliya}

Department of Plant Pathology, Junagadh Agricultural

University, Junagadh, Gujarat, India

\section{Rupapara}

Department of Plant Pathology, Junagadh Agricultural

University, Junagadh, Gujarat, India

\section{KS Jotangiya}

Department of Plant Pathology, Junagadh Agricultural

University, Junagadh, Gujarat, India
Corresponding Author: AG Ghaghara

Department of Plant Pathology, Junagadh Agricultural

University, Junagadh, Gujarat, India

\section{Efficacy of biocontrol agents against Fusarium oxysporum F. SP. Corianderi causing wilt of coriander under in vitro condition}

\author{
AG Ghaghara, VV Rajani, CM Bhaliya, MD Rupapara and KS Jotangiya
}

DOI: https://doi.org/10.22271/chemi.2020.v8.i1as.8718

\begin{abstract}
A laboratory experiment was conducted to find out the efficacy of different fungal and bacterial biocontrol agents against coriander wilt pathogen Fusarium oxysporum f. sp. corianderi. Among the seven antagonistic fungi tested using dual culture technique, Trichoderma harzianum JAU isolate 1 showed maximum reduced mycelial growth of Fusarium oxysporum f. sp. corianderi (46.23) than rest of antagonistic fungi. Whereas, the least effective biocontrol agent found was Trichoderma hamatum (NBA11 Tha 1) with 28.69 per cent mycelial growth inhibition of test fungus in vitro. The antagonistic actions of selected seven bacterial biocontrol agents were evaluated against the test fungus by dual culture technique (ring method). Among different bacterial antagonists, Pseudomonas fluorescens found significantly superior over rest of the biocontrol agents and showed maximum inhibition of mycelial growth of $F$. oxysporum f. sp. corianderi $(99.76 \%)$. While, the least effective biocontrol agent found was Bacillus subtilis (KT894726) with 72.08 per cent mycelial growth inhibition of test fungus in vitro.
\end{abstract}

Keywords: Fusarium oxysporum f. sp. corianderi, Coriander, biocontrol agents, coriander wilt

\section{Introduction}

Coriander is the second most important seed spice with respect to exports and getting foreign exchange earnings after cumin (Peter et al., 2006) ${ }^{[10]}$. Coriander is affected by many diseases which may be fungal, bacterial or viral. Among these, the wilt of coriander is a serious problem and affected plants grew poorly and were stunted. Root infection results in dropping of terminal shoots, followed by withering and drying of leaves. Partial infection shows yellow to pink foliage as disease progressed, plants eventually died (Prakasam et al., 1987) ${ }^{[12]}$. The seed yield losses caused by Fusarium wilt ranges from 5 to 60 per cent in Rajasthan and 15 to 25 per cent in Gujarat (Prasad and Patel, 1963) ${ }^{[13]}$. At present, the most of cultivated cultivars are susceptible to wilt disease causes up to 60 per cent yield loss in coriander (Manoranjitham et al., 2003) ${ }^{[6]}$. Use of biocontrol agents against wilt pathogen regarded as an effective tools for successful management of this disease. In order to evaluate efficacy of different fungal and bacterial biocontrol agents against test pathogen, present study was carried out in vitro.

\section{Materials and Methods}

Isolation and purification of pathogen

The plant showing typical characteristic symptoms of wilt disease were collected from the research farm and brought to the laboratory. The isolation of the fungus was made by tissue isolation technique on potato dextrose agar (PDA) and incubated at $28 \pm 2{ }^{\circ} \mathrm{C}$. The resulting fungal culture was purified in aseptic condition by hyphal tip method. The pure culture obtained was used for testing the efficacy of different fungal and bacterial biocontrol agents in vitro.

In vitro evaluation of fungal biocontrol agents against test pathogen

The antagonistic effect of seven different Trichoderma spp. viz., T. viride (NBAIITv23), Trichoderma harzianum JAU isolate 1, T. virens (NBAII Tvs12), T. hamatum (NBAII Tha 1), T. koningii (MTCC 2051), T. harzianum improved JAU isolate 1 and Trichoderma isolate DGR were tested against F. oxysporum $\mathrm{f}$. sp. corianderi using dual culture technique (Morton 
and Stroube, 1955) [9] in Completely Randomized Design (CRD) with three repetitions. Twenty milliliters of sterilized melted potato dextrose agar media (PDA) was poured aseptically in each $90 \mathrm{~mm}$ Petri plates and allowed to solidify. Mycelial disc of four millimeter diameter of each biocontrol agents and test fungus was cut with the help of sterilized cork borer from the edges of actively growing culture and was placed on the PDA medium in the same Petri plates, on opposite corners by keeping one $\mathrm{cm}$ distance from distal ends of Petri plates. The inoculated plates were incubated at $28 \pm 2$ ${ }^{\circ} \mathrm{C}$. The plates were observed for growth of biocontrol agents and test fungus periodically. The growth of biocontrol agents and test fungus was measured by linear measurement. Control plate was also maintained by placing two pathogen in the same plate, on opposite corner.

The radial growth of the test pathogen was measured when control plate pathogen contacted to each other. The per cent growth inhibition of the fungus by biocontrol agents in each treatment was calculated by using the following formula (Vincent, 1947).

$$
I=\frac{C-T}{C} \times 100
$$

Where,

$\mathrm{I}=$ Per cent reduction in growth of test pathogen

$\mathrm{C}=$ Radial growth $(\mathrm{mm})$ in control

$\mathrm{T}=$ Radial growth $(\mathrm{mm})$ in treatment

\section{In vitro evaluation of bacterial biocontrol agents against test pathogen}

The antagonistic effect of seven different bacterial isolates viz., Bacillus subtilis (KT894724), B. subtilis (KT894725), B. subtilis (KT894726), B. subtilis (KT894727), Pseudomonas fluorescens, B. subtilis and B. cereus and were tested against F. oxysporum $\mathrm{f}$. sp. coriander in $\mathrm{CRD}$ with three repetitions. The mycelia of F. oxysporum f. sp. corianderi was dualculture plated with different seven bacterial isolates as described by Montealegre et al. (2003) ${ }^{[8]}$. Twenty milliliters of sterilized melted nutrient agar (NA) media was poured aseptically in each $90 \mathrm{~mm}$ Petri plates and allowed to solidify. Mycelial disc of four millimeter diameter of test fungus was cut with the help of sterilized cork borer from the edges of actively growing culture and was placed in the centre of NA media containing Petri plates. A circular line made with a 60 $\mathrm{mm}$ diameter Petri plate dipped in a suspension of different bacterial species $(6 \times 108 \mathrm{cfu} \mathrm{ml}-1)$ surrounding the fungal inoculum. Plates were cultured for $72 \mathrm{~h}$ at $28+2{ }^{\circ} \mathrm{C}$ and the fungal growth was measured and compared with control growth where the bacterial suspension was replaced by sterile distilled water. The radial growth of the test pathogen was measured when control plate attain full growth of fungal pathogen. The per cent growth inhibition of the fungus by biocontrol agents in each treatment was calculated using the $\%$ Inhibition $=[1-($ Diameter of the lawn /Control growth $)] \times$ 100

\section{Results and Discussion \\ In vitro evaluation of fungal biocontrol agents against test pathogen}

The data presented in Table 1 indicated that among different fungal biocontrol agents tested in vitro, maximum reduction of pathogen (46.23 per cent) was observed in the presences of Trichoderma harzianum JAU isolate 1 followed by Trichoderma harzianum improved JAU isolate 1(42.92 per cent), Trichoderma viride (NBA11Tv23) (40.20 per cent), Trichoderma virens (NBA11 Tvs12) (37.41 per cent), Trichoderma koningii (MTCC 2051) (36.70 per cent) and Trichoderma isolate DGR (34.20 per cent). Trichoderma hamatum (NBA11 Tha 1) gave minimum growth inhibition with 28.69 per cent.

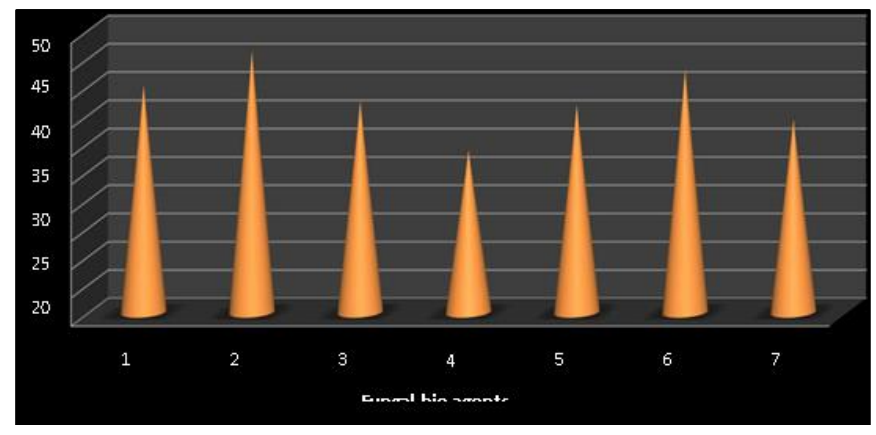

Fig 1: Mean inhibition per cent of fungal bio agents against $F$. Oxysporum F. SP. corianderi in vitro

\begin{tabular}{|c|c|c|c|}
\hline 1. & $\begin{array}{c}\text { Trichoderma viride } \\
\text { (NBA11Tv23) }\end{array}$ & 5. & $\begin{array}{c}\text { Trichoderma koningii } \\
\text { (MTCC 2051) }\end{array}$ \\
\hline 2. & $\begin{array}{c}\text { Trichoderma harzianum } \\
\text { JAU isolate } 1\end{array}$ & 6. & $\begin{array}{c}\text { Trichoderma harzianum } \\
\text { improved JAU isolate 1 }\end{array}$ \\
\hline 3. & $\begin{array}{c}\text { Trichoderma virens } \\
\text { (NBA11 Tvs12) }\end{array}$ & 7. & Trichoderma isolate DGR \\
\hline 4. & $\begin{array}{c}\text { Trichoderma hamatum } \\
\text { (NBA11 Tha 1) }\end{array}$ & & \\
\hline
\end{tabular}

Table 1: In vitro evaluation of fungal biocontrol agents against test pathogen

\begin{tabular}{|c|c|c|}
\hline Sr. No. & Fungal bio agents & \#Growth inhibition (\%) \\
\hline 1 & Trichoderma viride (NBA11Tv23) & $* 39.35(40.20)$ \\
\hline 2 & Trichoderma harzianum JAU isolate 1 & $42.84(46.23)$ \\
\hline 3 & Trichoderma virens (NBA11 Tvs12) & $37.71(37.41)$ \\
\hline 4 & Trichoderma hamatum (NBA11 Tha 1) & $32.39(28.69)$ \\
\hline 5 & Trichoderma koningii (MTCC 2051) 37 & $.29(36.70)$ \\
\hline 6 & Trichoderma harzianum improved JAU isolate 1 40 & $.93(42.92)$ \\
\hline 7 & Trichoderma isolate DGR 35 & \\
\hline S.Em. \pm & & $0.79(34.20)$ \\
\hline CD at 5\% & 0. & \\
\hline CV\% & 1.39 & \\
\hline
\end{tabular}

(\# Average of three replications *Data outside the parenthesis are arcsine transformed whereas inside are re-transformed values)

The present findings are in close agreement with the results obtained by workers viz., Baradia and Rai (2007) ${ }^{[1]}$, Lodha and Singh (2007) ${ }^{[5]}$ and Deepak et al. (2008) ${ }^{[2]}$ against
Fusarium oxysporum F. SP. cumini, Suman and Biswas (2017) ${ }^{[16]}$, Praful and Mane (2017) ${ }^{[11]}$ and Mayur et al. (2001) ${ }^{[7]}$ against Fusarium oxysporum f. sp. ciceri and Jat et 
al. (2017) ${ }^{[4]}$ against Fusarium oxysporum f. sp. corianderi.

In vitro evaluation of bacterial biocontrol agents against test pathogen

The perusal of data in Table 2 Among the seven antagonistic bacteria tested Pseudomonas fluorescens showed maximum reduced mycelial growth of Fusarium oxysporum f. sp. corianderi than rest of antagonistic bacteria. Maximum reduction of pathogen (99.76) was observed in the presences of Pseudomonas fluorescens followed by Bacillus subtilis (KT894727) (94.75 per cent), Bacillus subtilis (84.63 per cent), Bacillus cereus (83.68 per cent), Bacillus subtilis (KT894724) (79.43 per cent), Bacillus subtilis (KT894725) (73.84 per cent). Bacillus subtilis (KT894726) gave minimum growth inhibition with 72.08 per cent.

The present findings are in collaborate with the results obtained by different workers. The antagonistic effect of Pseudomonas fluorescens against Fusarium oxysporum f. sp. ciceri (Rajan et al., 2013) ${ }^{[14]}$, Pseudomonas aeruginosa against Fusarium oxysporum f. sp. cumini (Sobhanipour et al., 2008) ${ }^{[15]}$ and Bacillus subtilis against F. oxysporum f. sp. vasinfectum,
Rhizoctonia solani and Macrophomina phaseolina (Hoda-Ahmed et al. 2000) ${ }^{[3]}$ was reported by several workers.

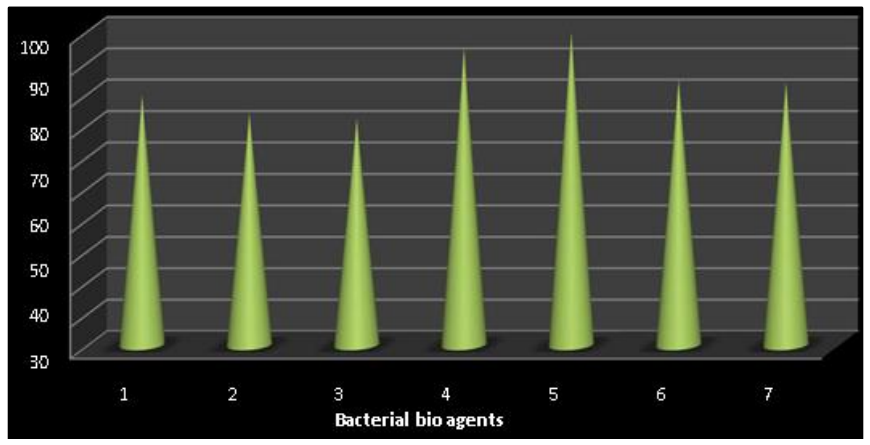

Fig 2: Mean inhibition per cent of bacterial bio agents against $F$. oxysporum $F$. SP. corianderi in vitro

\begin{tabular}{|l|c|c|c|}
\hline 1. & Bacillus subtilis (KT894724) & 5. & Pseudomonas fluorescens \\
\hline 2. & Bacillus subtilis (KT894725) & 6. & Bacillus subtilis \\
\hline 3. & Bacillus subtilis (KT894726) & 7. & Bacillus cereus \\
\hline 4. & Bacillus subtilis (KT894727) & & \\
\hline
\end{tabular}

Table 2: In vitro evaluation of bacterial biocontrol agents against test pathogen

\begin{tabular}{|c|c|c|}
\hline Sr. No. & Bacterial bio agentsGr & Owth inhibition (\%) \\
\hline 1. & Bacillus subtilis (KT894724) 6 & $.04 *(79.43)$ \\
\hline 2. & $\begin{array}{l}\text { Bacillus subtilis (KT894725) } 5 \\
\end{array}$ & $.24(73.84)$ \\
\hline 3. & Bacillus subtilis (KT894726) 5 & $.10(72.08)$ \\
\hline 4. & $\begin{array}{l}\text { Bacillus subtilis (KT894727) } \\
7\end{array}$ & $.80(94.75)$ \\
\hline 5. & Pseudomonas fluorescens 87 & $.27(99.76)$ \\
\hline 6. & Bacillus subtilis & $.93(84.63)$ \\
\hline 7. & Bacillus cereus & $.18(83.68)$ \\
\hline S.Em. + & & \\
\hline \multicolumn{2}{|r|}{$\mathrm{CD}$ at $5 \% 1$} & \\
\hline CV\% & & \\
\hline
\end{tabular}

\section{References}

1. Bardia PK, Rai PK. In vitro and field evaluation of biocontrol agents and fungicides against wilt of cumin caused by Fusarium oxysporum f. sp. cumini. J Spices Arom. Crops. 2007; 16(2): 88-92.

2. Deepak P, Saran L, Lal G. Control of wilt and blight diseases of cumin through antagonistic fungi under in vitro and field conditions. Not. Bot. Hort. Agrobot. Cluj. 2008; 36(2):91-96.

3. Hoda Ahemed El, Moneem AM, Allam AD, Fahymy FGM. Biological control of root-rots and wilt diseases of cotton. Assiut J Agri. Sci. 2000; 31(2):269-285.

4. Jat MK, Ahir RR, Kakraliya GL. Evalution of fungicides as seed treatment against coriander wilt and disease caused by Fusarium oxysporum f. sp. corianderi. Int. J Pl. Prot. 2017; 10:92-95.

5. Lodha S, Singh V. Bio-control potential of Aspergillus versicolor in managing cumin wilt pathogen Fusarium oxysporum f. sp. cumini. In Production, Development, Quality and Export of Seed Spices. S. K. Malhotra and B. B. Vashishtha (Eds.). National Research Centre on Seed Spices (ICAR) Ajmer- 305 206, Rajasthan, India. 2007, 293-299.

6. Manoranjitham SK, Rabindram R, Doraiswamy S. Management of seed borne pathogens and wilt disease of coriander. Madras Agri. J. 2003; 90:4-6.

7. Mayur D, Jani SM, Deshmukh VV. Effect of fungicides against Fusarium oxysporium f. sp. ciceri a chickpea wilt pathogen. Ann. Pl. Physiol. 2001; 15(2):147-149.

8. Montealegre JR, Reyes R, Perez LM, Herrera R, Silva P, Besoaim X. Selection of bio antagonistic bacteria to be used in biological control of Rhizoctonia solani in tomato. Electron J Biotechnol, 2003, 6(2). http://www.ejbiotechnology.info/content/vol6/issue2/full/ 8. (Accessed on 13.2. 2018).

9. Morton DJ, Stroube WH. Antagonistic and stimulating effects of soil microorganism of Sclerotium. Phytopathology. 1955; 45:417-420.

10. Peter KV, Nyb EV, Mini-Raj N. Available technologies to rise yield. The Hindu Sur. Agri. 2006; 5:82-86.

11. Praful K, Mane SS. Efficacy of fungicides and biocontrol agents against Fusarium oxysporum f. sp. ciceri. Int. J Curr. Microbiol. App. Sci. 2017; 6(3):1450-1455.

12. Prakasam V, Vedamuthu PGB, Khader MA, Jayarajan R. Screening coriander lines for wilt resistance. S. Indian Hort. 1987; 35:258-259.

13. Prasad N, Patel PN. Fusarium wilt of cumin in Gujarat state, Indian Pl. Dis. Report. 1963; 47(6):528-531.

14. Rajan PV, Saifulla M, Pallavi MS. In vitro evaluation of bio-agents, fungicides and herbicides against Fusarium oxysporum f. sp. ciceri causing wilt of chickpea. Bionfolet, 2013, 10(2a).

15. Sobhanipour A, Etebarian HR, Roostaee MA, Khodakaramian G, Aminian H. Biological control of Fusarium wilt of cumin by antagonistic bacteria. J Agri. Sci. Guilan. 2008; 1(10):41-50.

16. Suman P, Biswas MK. Eco-friendly management of Fusarium oxysporum f. sp. ciceri the causal agent of chickpea wilt disease under in-vitro condition. Int. J Curr. Microbiol. App. Sci. 2017; 6(3):1852-1858. 